\title{
O9 当院におけるEBUS-TBNAによるサルコイドーシスの診断
}

○水守康之, 福田 泰, 大西康貴, 加藤智浩, 白石幸子, 鏡 亮吾, 勝田倫子, 三宅剛平, 横井洋子, 塚本宏壮, 守本明枝, 佐々木信, 河村哲治, 中原保治, 望月吉郎

国立病院機構姫路医療センター 呼吸器内科

【背景】近年，サルコイドーシス診断にけるEndobronchial ultrasound-guided transbronchial needle aspiration (EBUSTBNA）の有用性が報告されている. 当院においても臨床的にサ ルコイドーシスが疑われる症例では, 穿刺可能な縦隔リンパ節病 変がある場合はEBUS-TBNAを検査の第一選択としている.

【目的】サルコイドーシス診断におけるEBUS-TBNAの成績につ いて検討する。

【対象】2012年4月～2014年7月に当院で組織診断サルコイドーシ スと診断された47例のうち, 縦隔リンパ節に対してEBUS-TBNA が施行された 33 例.

【方法】サルコイドーシスのEBUS-TBNAによる組織学的診断率 およびEBUS-TBNAで診断が得られなかった際の診断根拠につい て検討した，使用した穿刺針は31例が21G（型番NA-205X-4021;
Olympus)，残 る2例 が22G（SonoTip ${ }^{\circledR}$ EBUS Pro Flex; MediGlobe）であった.

【結果】EBUS-TBNAによりサルコイドーシスの組織学的診断が 得られた症例は33例中30例（90.9\%）であった。全例で組織検体 がえられたが，診断が得られなかった 3 例の検体はいずれもリン パ組織の細片のみでサルコイドーシスに特徵的な病理所見を認め なかった. EBUS-TBNAで診断が得られなかった 3 例のうち1例は 胸腔鏡下肺生検, 2例は縦隔鏡検査で確定診断された.

【まとめ】EBUS-TBNAは縦隔リンパ節腫大を有するサルコイドー シスの診断法として有用と考えられた．穿刺部位や回数などとの 関連なども含めて報告したい

\section{0 本邦サルコイドーシスの地域別臨床像}

服部健史 ${ }^{1,2)}$, 今野 哲 ${ }^{2)}$, 四十坊典晴 ${ }^{3)}$ ，山口哲生 ${ }^{4)}$, 杉山幸比古 ${ }^{5)}$, 西村正治 ${ }^{2)}$

国立病院機構北海道医療センター 呼吸器内科 ${ }^{1)}$

北海道大学病院 内科 $\mathrm{I}^{2)}$

$J R$ 札幌病院 呼吸器内科 ${ }^{3)}$

$J R$ 東京総合病院 呼吸器内科 ${ }^{4)}$

自治医科大学 呼吸器内科 5 )

【背景】サルコイドーシスでは，以前から地域集積性を指摘され てきたが，地域別の臨床像については明らかにはされていない. 【目的】サルコイドーシスの地域別臨床像を検討すること. 【方法】対象は，2001年度から2011年度の間に組織学的に新規診 断され，特定疾患申請されたサルコイドーシス患者11,033名．全 国の都道府県から回収された臨床調査個人票を用いて, 八地方区 分で層別化し，男女別で各群に打ける臨床像について比較した。

【結果】中央值年齢は男女ともに群間で有意差を認め, 東北地方 が最も中央值年齢が低かった。両側肺門リンパ節腫大，び漫性肺 病変, 眼病変, 皮䖉病変, 心電図異常の有無は女性では群間で有
意差を認めたが，男性では差を認めなかった。緯度に依存した分 布の違いは明らかではなかったが，女性において，眼病変の割合 は北海道地方が最も高く, 皮膚病変と心電図異常の割合は四国地 方が最も高かった。

【結論】臨床調査個人票を用いたサルコイドーシスの臨床像は各 地方で異なった.

\section{O11 Pleuroparenchymal fibroelastosis（PPFE）における肉芽腫性病変}

中尾 明 ${ }^{1)}$, 井形文保 ${ }^{1)}$, 吉田祐士 ${ }^{1)}$, 矢次 博 $^{1)}$, 佐々木朝矢 ${ }^{1)}$, 森重真美 ${ }^{1)}$, 石井 寛 ${ }^{1)}$, 鶴田伸子 ${ }^{2)}$, 永田忍彦 ${ }^{3)}$, 渡辺憲太朗 ${ }^{1)}$

福岡大学病院 呼吸器内科 1 )

国家公務員共済組合連合会 浜の町病院 ${ }^{2)}$

福岡大学筑紫病院 呼吸器内科 ${ }^{3)}$

特発性PPFE以外に, 移植, アスペルギルス感染, 自己免疫学 的機序など，様々な基礎病態がPPFEの発症に関与する可能性 があると報告されている. 今回, 外科的肺生検もしくは剖検で PPFEと診断した症例の中で, 組織学的に肉芽腫が証明された2 例と, 喀痰から非結核性抗酸菌（NTM）が検出された 3 例（計4例; 1例は重複）について報告し, PPFEの発症・進展における肉芽 腫の関与について考察する。

【症例1】48歳, 女性. 右気胸で入院し, 切除肺でPPFEと診断さ れたが，組織中に肉芽腫も確認された。気胸発症 2 年後より喀痰 からM. aviumが検出され，呼吸不全で死亡した。

【症例2】49歳, 女性. 外科的肺生検で過敏性肺炎を疑わせる肉芽 腫が肺胞隔壁に多発し，PPFEも併存していた，12年後の再生検
でPPFEの進展があったが, 肉芽腫は消失していた、NTMは検 出していない.

【症例3】53歳, 女性. 関節リウマチがあり, 外科的肺生検で PPFEと診断され，喀痰から3度NTMが検出された。

【症例4】56歳, 女性. 肺病変が13年の経過で進行し, 剖検で PPFEと診断された. 生前, 喀痰から2度NTMが検出されていた。 